\title{
The Engineering Design Log: A Digital Design Journal Facilitating Learning and Assessment (RTP)
}

\section{Dr. Roxanne Moore, Georgia Institute of Technology}

Roxanne Moore is currently a Research Engineer at Georgia Tech with appointments in the school of Mechanical Engineering and the Center for Education Integrating Mathematics, Science, and Computing (CEISMC). She is involved with engineering education innovations from K-12 up to the collegiate level. She received her Ph.D. in Mechanical Engineering from Georgia Tech in 2012.

\section{Dr. Meltem Alemdar, Georgia Institute of Technology}

Dr. Meltem Alemdar is Assistant Director and Research Scientist II at Georgia Tech's Center for Education Integrating Science, Mathematics, and Computing (CEISMC). Dr. Alemdar has experience evaluating programs that fall under the umbrella of educational evaluation, including K-12 educational curricula, K-12 STEM programs after-school programs, and comprehensive school reform initiatives. Across these evaluations, she has used a variety of evaluation methods, ranging from a multi-level evaluation plan designed to assess program impact to methods such as program monitoring designed to facilitate program improvement. She received her Ph.D. in Research, Measurement and Statistics from the Department of Education Policy at Georgia State University (GSU).

\section{Dr. Jeremy A. Lingle, Georgia Institute of Technology}

Dr. Jeremy Lingle is a Research Faculty at the Center for Education Integrating Science, Mathematics, \& Computing (CEISMC) at the Georgia Institute of Technology. He received his Ph.D. in Educational Policy Studies in Research, Measurement, and Statistics in 2010 from Georgia State University. His primary research focus is upon STEM integration in K-12 education and program evaluation.

\section{Dr. Sunni Haag Newton, Georgia Institute of Technology}

Sunni Newton is currently a Research Associate II at the Georgia Institute of Technology in the Center for Education Integrating Science, Mathematics, and Computing (CEISMC). Her research focuses on assessing the implementation and outcomes of educational interventions at the K-12 and collegiate levels. She received her MS and Ph.D. in Industrial/Organizational Psychology from Georgia Tech in 2009 and 2013, respectively. She received her BS from Georgia Tech in 2006, double-majoring in Psychology and Management.

\section{Mr. Jeffrey H Rosen, Georgia Institute of Technology}

After 14 years in the middle and high school math and engineering classroom where Mr. Rosen was working on the integration of engineering and robotics into the teaching of the core curricula classrooms. He has now been at Georgia Tech's CEISMC for the past 8 years working on curriculum development and research on authentic STEM instruction and directing the state's FIRST LEGO League competition program. Mr. Rosen has authored or co-authored papers and book chapters that address issues of underrepresented populations participation in engineering programs and the integration of robotics and engineering into classroom instruction.

\section{Dr. Marion Usselman, Georgia Institute of Technology}

Marion Usselman is a Principal Research Scientist and Associate Director for Federal Outreach and Research at the Georgia Institute of Technology's Center for Education Integrating Science, Mathematics and Computing (CEISMC). She earned her Ph.D. in Biophysics from the Johns Hopkins University and has been with CEISMC since 1996 developing and managing university-K-12 educational partnership programs. She currently leads up a team of educators and educational researchers who are exploring how to integrate science, mathematics and engineering within authentic school contexts and researching the nature of the resultant student learning 


\title{
The Engineering Design Log: A Digital Design Journal Facilitating Learning and Assessment (RTP)
}

\begin{abstract}
Students engaging in design and engineering processes are frequently encouraged to keep a notebook, journal, or log containing their drawings, reflections, decisions, and justifications. In the professional world, such a notebook is primarily for the benefit of the designer, to keep track of important ideas and data and to protect intellectual property. In engineering education, a notebook or other process documentation is often incorporated into instruction as a pedagogical tool and is used by teachers for assessment; the intent is to assess the student's solution process separately from their design artifacts. However, there is little agreement among curriculum developers and practitioners about how best to ensure that students keep a thorough enough document trail to allow teachers to follow and assess a student's design process. Even at the college level, design processes are typically assessed only through reports and presentations without a standardized format or rubric. While previous work in this area has focused on the development of a rubric for engineering design portfolios at the college level, there were no suggested portfolio formats, and the rubrics were not piloted specifically at the K-12 level.
\end{abstract}

To help students and teachers in K-12 settings navigate and assess engineering design, researchers at Georgia Institute of Technology have developed an electronic Engineering Design Process Log to guide the engineering design process, its documentation, and its assessment. This log, when coupled with supplemental reflections, can be used in conjunction with a newly adapted set of rubrics to assess student understanding and application of the Engineering Design Process (EDP) at the middle and high school levels. For students who are novices in following the EDP, such a log can also serve as a guide, providing cues about the necessary components and activities associated with each step in the process and encouraging students not to miss or fail to complete steps.

There are two primary contributions in this paper. The first is to present a detailed description of the EDP log and rubrics for middle and high school classrooms, along with student data and artifacts. The rationale for the EDP $\log$ will be explained, including parallels to engineering design courses at Georgia Tech. The second contribution is a comparison of the EDP log with other engineering notebook paradigms. Qualitative data from both middle and high school teachers is provided to illustrate the use of different engineering notebook paradigms in classroom settings. Interview and focus group results are presented using thematic analysis, a processoriented approach involving a systematic technique of identifying and coding themes. 


\section{Introduction}

With the increased emphasis on Science, Technology, Engineering, and Mathematics (STEM) in education, many educators are teaching the engineering design process in technology, engineering, and science classrooms. While there are many published versions of the Engineering Design Process (EDP) and no one model is generally accepted, the overarching concepts are generally consistent between university engineering courses ${ }^{1}$, high school engineering courses ${ }^{2}$, and the Next Generation Science Standards ${ }^{3}$. The specific sequence or semantics of the process is less important than the systematic, iterative nature that characterizes the EDP as being an important part of engineering.

In both K-12 and university engineering design courses and activities, there is a difference between the design process followed and the design artifact that is produced by said process. A student may produce an excellent design artifact while not following a rigorous design process; similarly, a student may produce an artifact that is incomplete or does not function as intended while following a very systematic and meaningful process. This is an important distinction; the first student may have been working on a problem for which he or she had some intuition or past experience and may not be able to repeat this success in subsequent challenges. The second student may be on a very positive trajectory but may run into a deadline or unexpected challenge before achieving a successful design. For these reasons, the design process and the design artifact need to be assessed independently. However, it is hard not to conflate the process and the artifact when grading student work, and the scoring of both is subjective ${ }^{4}$.

Requiring a document in which students are tasked with recording their work as they move through the steps of the engineering design process has been offered as part of good practice in engineering instruction ${ }^{4,5}$. These documents, which can take the name of engineering design portfolio, notebook, journal, or log based on their contents and use, are intended to serve as a central location for students to collect and review such work products as problem scoping, brainstorming, notes, research, sketches, procedures, data from tests, detailed drawings and any other relevant information that led to design decisions ${ }^{5,6}$. This is consistent with industry practice, where engineers must undergo design reviews and protect their intellectual property. However, many students and professional engineers make decisions without systematic processes and without adequate documentation. This is particularly challenging in K-12 settings where students are often not accustomed to writing or to process-centric learning, particularly in their engineering and technology classes.

As part of a National Science Foundation Math Science Partnership at Georgia Tech called Advanced Manufacturing and Prototyping Integrated to Unlock Potential (AMP-IT-UP), we have developed an electronic engineering notebook to support engineering design coursework at the middle and high school levels. The electronic notebooks have associated rubrics to be used for 
both research and grading purposes, and these rubrics have been tailored specifically to both the middle school and high school audiences. In this paper, a description of the engineering notebook, known as the Engineering Design Process Log or EDP Log, and the associated rubrics are provided. This is accompanied by feedback from teachers about the benefits and challenges of using the EDP logs in the classroom after one or more semesters of implementing the AMP-ITUP curriculum. The remainder of the paper is organized as follows. First, relevant literature is presented. Then, the EDP Log is described in more detail. Next, data from teacher interviews and student artifacts is presented. Finally, we discuss revisions, curricular impacts, conclusions, and future work.

\section{Literature Survey: Engineering Design Notebooks}

In this literature review, various potential benefits of engineering design notebooks will be discussed. Next, evidence from K-12 and undergraduate level design log usage will be presented, along with the successes and challenges accompanying this use. Finally, a review of assessment strategies pertaining to engineering notebooks will be provided, with a focus on using rubrics in the assessment of these documents.

Potential Benefits of Engineering Notebooks: Numerous potential benefits of using Engineering Notebooks (EN's) or logs in the context of engineering instruction at various educational levels have been discussed throughout the engineering education literature. A key purpose of using EN's is to help students more clearly define and understand the design problem 5 . Keeping detailed records of design decisions and thought processes allows students to review their work at a later date and helps others to follow their design processes ${ }^{5}$. The act of keeping the $\log 5$ encourages self-reflection with respect to design problems and processes ${ }^{7}$. Keeping an EN provides evidence of a process, as opposed to simply outcomes or final products, which are more typically collected and graded than a student's design process ${ }^{4}$. One author has suggested that "engineering education might be insisting on truth at the expense of conceptual thinking"4. EN's offer a concrete way to allow students to move beyond finding "truth" or the "right answer". The EN carries a high level of real-world relevance, and allows for an assessment that is both "authentic" and "performance" based".

Engineering Notebook Usage, Successes, and Challenges: Use of EN's at various educational levels and within multiple educational contexts has been described and evaluated in the literature. At the middle school level, EN's have been used in design process instruction in science classrooms ${ }^{9}$ and across various design challenges for grades $5-9^{7}$. At the high school level, EN's have been used in both engineering ${ }^{10,11}$ and genetics courses ${ }^{12}$. In addition, at the undergraduate level, EN's have been used in robotics ${ }^{13}$, biomedical engineering ${ }^{14}$, and seniorlevel, project-based engineering courses ${ }^{15}$.

Within these contexts, authors have noted some successful results in the use of EN's. A case study of three high school engineering courses provided evidence that EN's were useful for 
planning and recording daily activities ${ }^{10}$. EN's in an undergraduate biomedical engineering course contained evidence of students' self-reflection and suggested an increase over time in the maturity level of students' engineering practice; these authors concluded that "the design notebook fulfilled an instrumental... pedagogical role as part of engineering practicum" 14 .

Multiple challenges have also been noted in educators' attempts to introduce EN's to their classrooms. In general, there is a lack of clarity as to what an EN should contain and why it should be kept ${ }^{5}$. Authors also note difficulties in motivating students to complete EN's, a finding echoed in our own results: "few students seem to see any intrinsic value in careful record keeping"7. Students were also reluctant to engage in self-reflection in their documentation of activities; they would record that a problem had occurred, but usually did not reflect on why the problem occurred or how to address it $^{10}$.

A case study of three high school engineering classes indicated a strong link between teacher instructions and student log usage. Students used the notebooks only in ways specified by their teachers. An additional finding from this study is that in each class, a single step of the design process (which varied by class) was most prevalent in the design notebooks, indicating that it may be challenging to combine the different needs of the various steps in a single document ${ }^{10}$. Many of these challenges were considered in the formulation of our EDP log.

Engineering Notebook Scoring and Grading: The use of EDP logs for engineering instruction requires consideration of how such an assignment can and should be graded ${ }^{16}$. Many engineering education researchers have recognized challenges associated with assessing the engineering design process and noted that further research and developments in this area are needed ${ }^{17-21}$. Engineering design process instruction and student activities are often complex, build on earlier instruction, benefit from multiple iterations, and cover multiple learning domains. As such, they are ideally evaluated with an assessment strategy that is largely performance-based, including some pre-and post-test measurements, both formative and summative data, and both quantitative and qualitative data $17,18,20$.

Existing performance-based assessment methodologies focus on evaluation of student work (e.g., student portfolios, engineering notebooks or logs, individual or group presentations) ${ }^{17,20-22}$, and have also included efforts to assess student attitudes via self-report questionnaires ${ }^{23}$. These assessments tend to be primarily qualitative and subjective, although efforts to increase the objectivity of such assessments have been made with the introduction and validation of the Engineering Design Process Portfolio Scoring Rubric (EDPPSR) ${ }^{17,19}$, a set of standardized rubrics for evaluating learning outcomes of the engineering design process. A modification of the EDPPSR was used for the evaluation in the current study, discussed in more detail in the data source section below. The high school adaptation developed is provided in Appendix A and the middle school adaptation is provided in Appendix B. 


\section{Engineering Design Process Log Description}

In the development of the EDP $\log$, the authors attempted to distill the most important aspects of each step in the Engineering Design Process used in the engineering courses developed. The EDP developed and used for this work is shown in Figure 1, below. As there is not one universally accepted EDP, there is also not one universally accepted approach for each of the steps in the EDP. For example, 'ideation' is generally understood to be a step about brainstorming different possible design concepts, but there are many different ideation and brainstorming strategies advocated by various members of the design community. It was necessary to provide scaffolding for students to provide clear evidence of their design process while still being authentic and flexible. The EDP log is not a replacement of a full engineering or design notebook; rather, it is the summary document from which most of the process information can be gleaned. It should then be supplemented with additional student reflections and other data, drawings, instruments, and research that may not fit within the constructs set forth in the EDP log itself.

\section{Engineering Design Process}

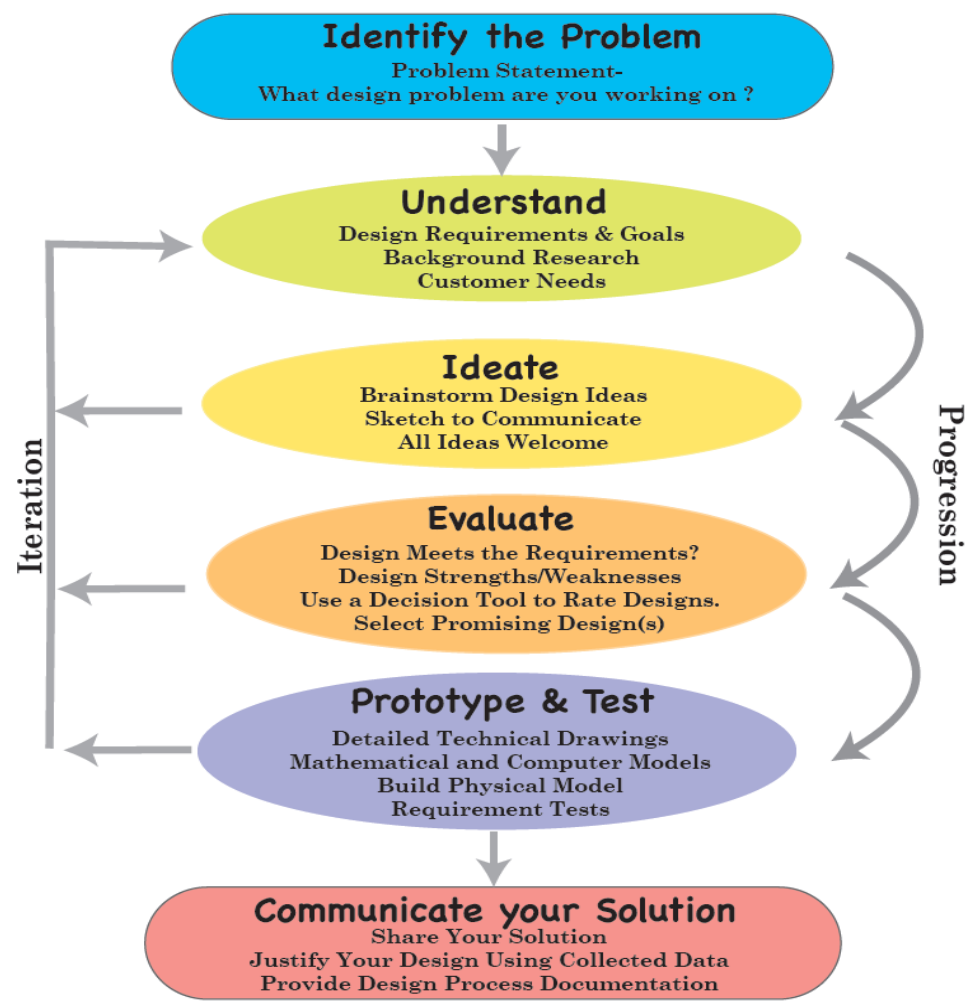

Figure 1: Engineering Design Process

The EDP log is implemented in both Microsoft Excel and Google Sheets. The Google Sheets version is compatible with Google classroom, which is used by teachers participating in our math science partnership. Each tab contains one or two steps of the EDP, and relevant information 
from previous tabs is automatically propagated throughout the document to reduce the writing load on the students. Snapshots of the various pages of the EDP $\log$ and descriptions are provided below.

The 'Identify \& Understand' tab maps directly to the 'Identify the Problem' and 'Understand' steps of the EDP and is shown in Figure 2, below. These steps are among the most important in the EDP and possibly the most often overlooked. In the 'Identify' portion, the students are asked to describe the problem that they are trying to solve. Then, in the 'Understand' portion, students are asked to provide a dated list of design requirements labeled with appropriate sources. This entire tab should be solution-agnostic; that is, neither the problem description nor the requirements should imply a particular solution. Specific instructions to the student are given in notes attached to the cells; these are depicted in text labels in Figure 2. For more details about filling out this tab and expectations on student achievement, see the rubrics provided in Appendices A \& B.

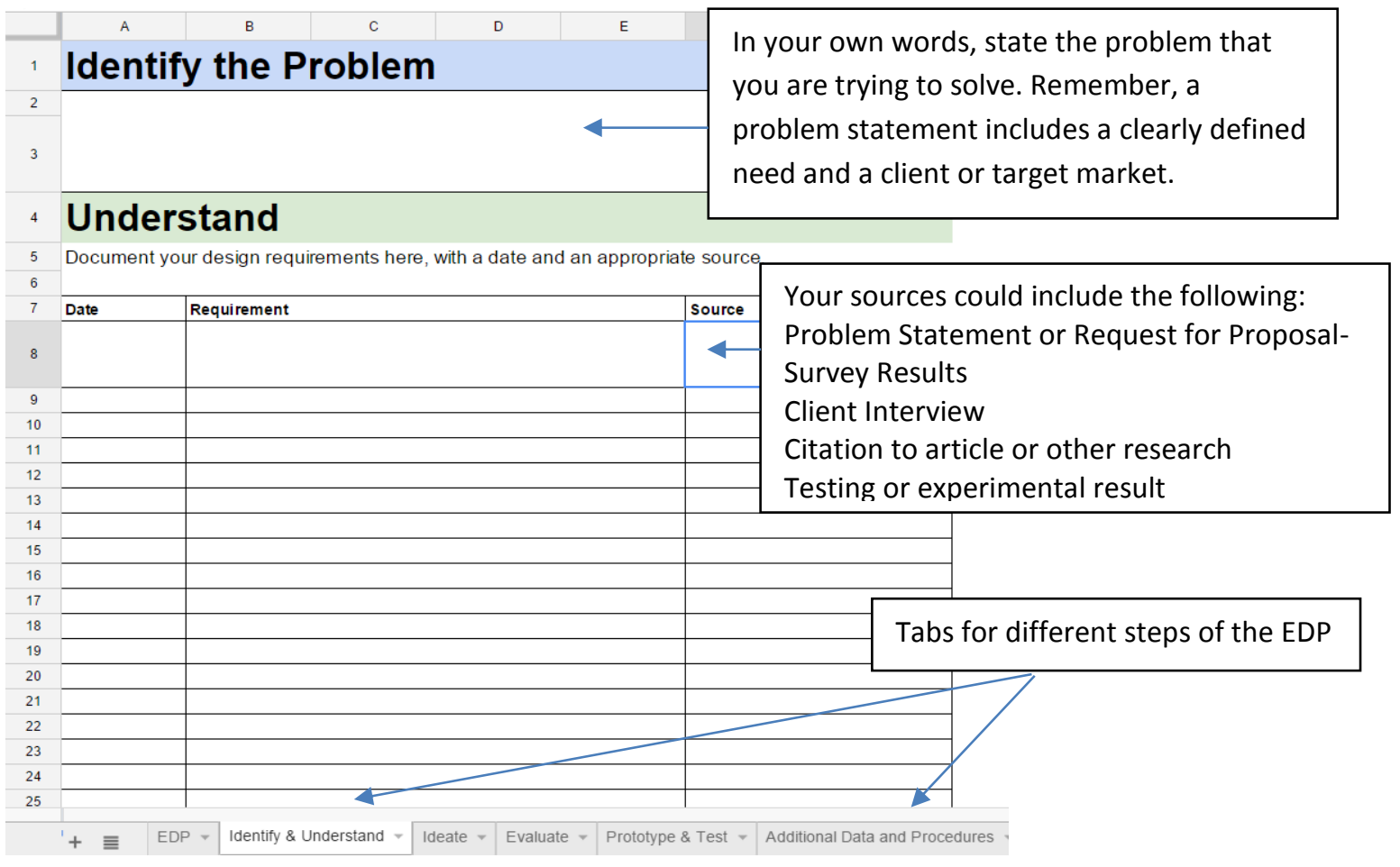

Figure 2: EDP Log, Identify \& Understand

The 'Ideate' and 'Evaluate' tabs map directly to the 'Ideate' and 'Evaluate' steps of the EDP and are shown in Figures 3 and 4, below. The ideate tab is used to document sketches or computer drawings of design concepts brainstormed. There is space for both a picture and a basic description of each design artifact. The design requirements from the 'Identify \& Understand' tab propagate automatically to both the Ideate and Evaluate tabs. These requirements should be used to help with brainstorming during the Ideate phase and should be used for preliminary evaluation of design concepts on the Evaluate tab. The Ideate tab is very revealing in terms of both design 
fixation and iteration. If a student has only one design concept, there is strong evidence of design fixation; that is, the student had one solution in mind from the beginning of the process and did not truly consider the design and customer requirements. To circumvent this, educators often require at least three unique design concepts. Ideally, during iteration, additional concepts are brainstormed based on initial test results.

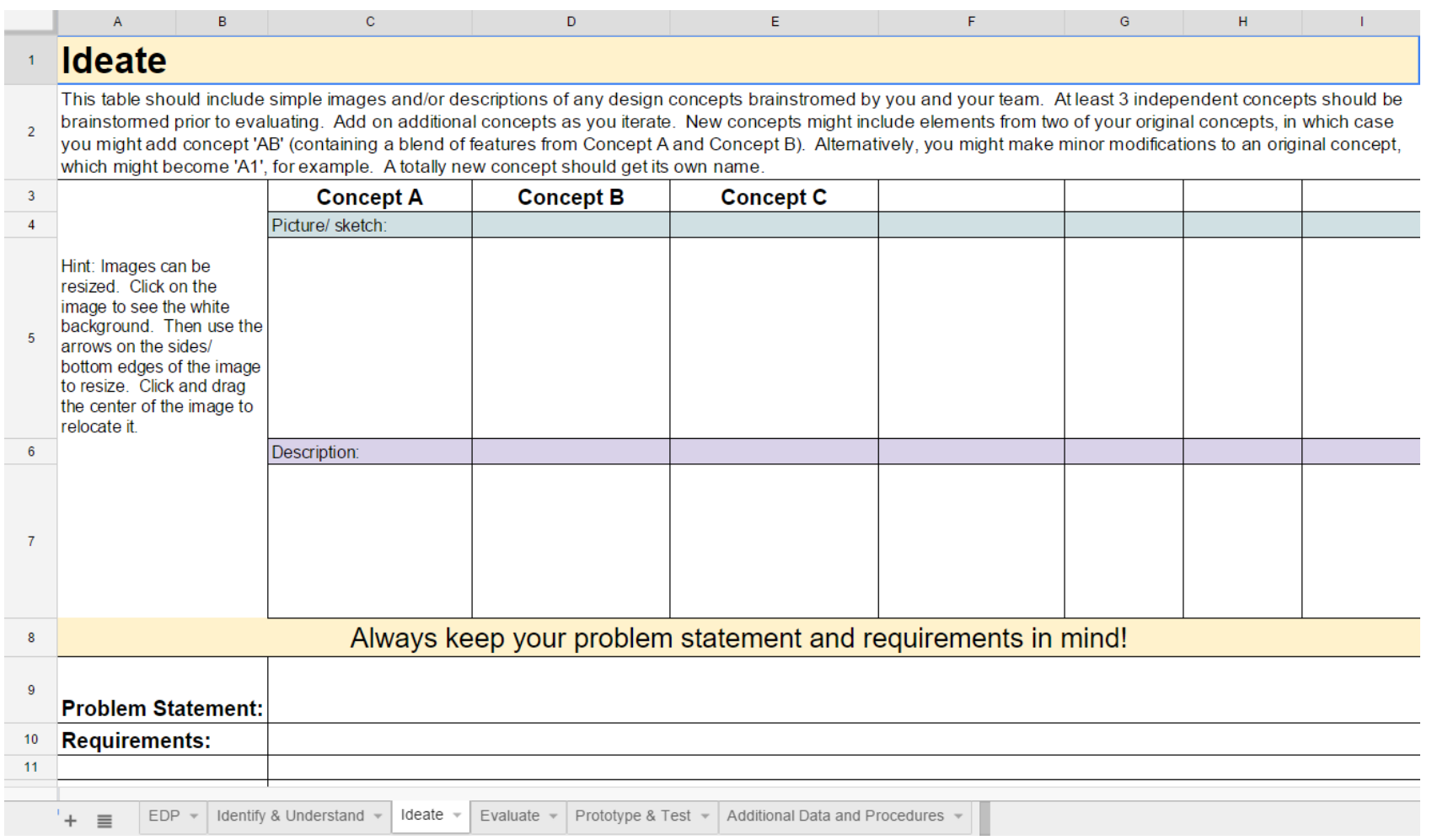

\section{Figure 3: EDP Log, Ideate}

On the Evaluate tab, the design descriptions auto-populate from the Ideate tab, along with the design requirements. Students are then asked to predict whether or not each concept is likely or unlikely to meet each of the requirements. These are just beliefs or predictions, but they should be used to help the students to decide which concept(s) are most promising for further development and prototyping. When a student enters an ' $L$ ' for likely or a ' $U$ ' for unlikely, the gray cells turn green or red, respectively. 


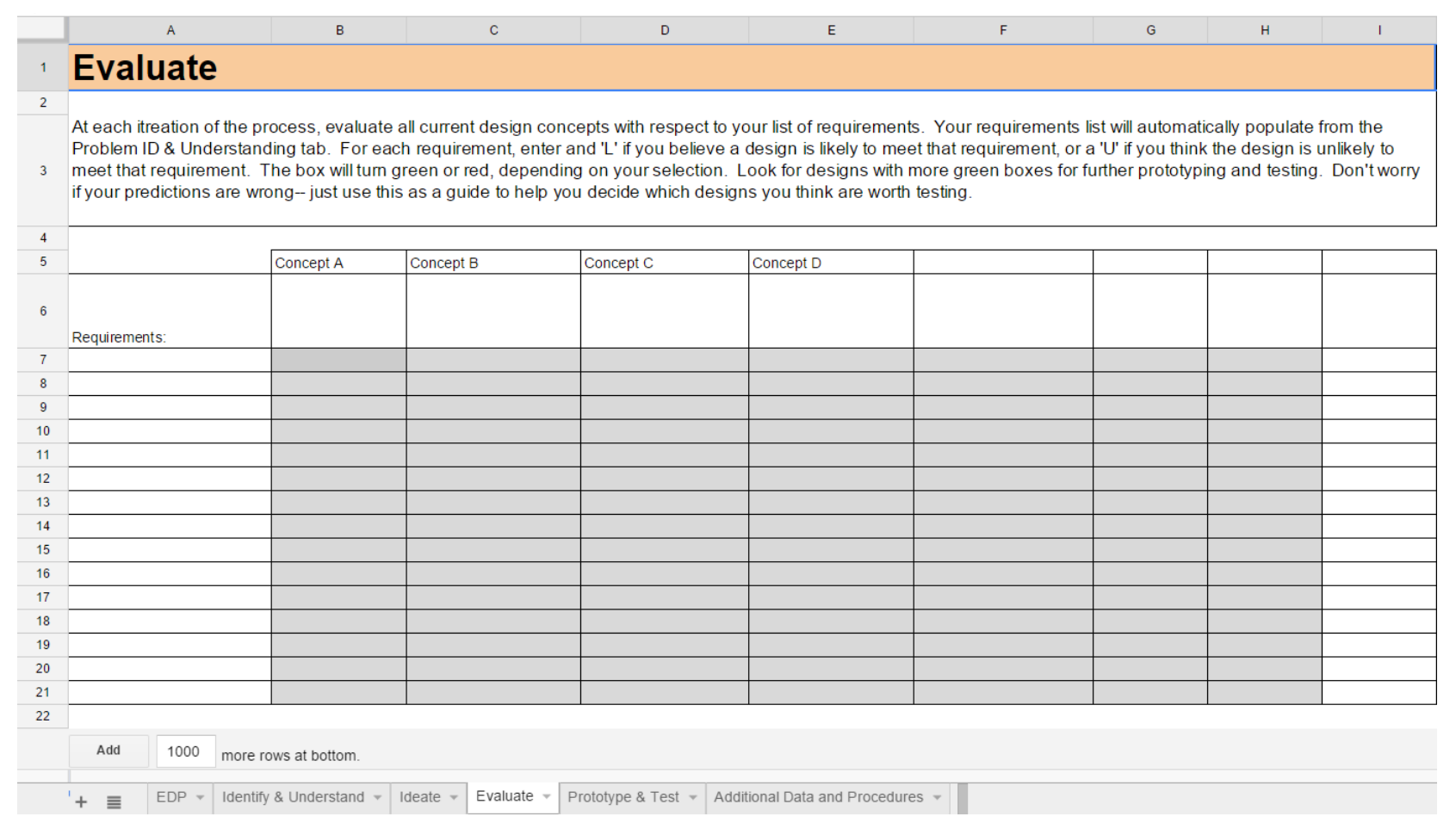

Figure 4: EDP Log, Evaluate

The 'Prototype \& Test' tab maps directly to the 'Prototype' and 'Test' steps of the EDP and is shown in Figure 5, below. The Prototype \& Test tab is the richest and most detailed of all of the tabs. Only one iteration of prototyping is captured in the figure, but there is room for multiple prototypes and iterations to be documented. For each prototype, there is space for a picture of the physical artifact or a detailed computer drawing. For each requirement, populated again from the Identify \& Understand tab, the student is asked to briefly explain the test used to verify whether or not the prototype met the requirement. The student enters a ' $\mathrm{Y}$ ' for Yes if the requirement is satisfied, or an ' $\mathrm{N}$ ' for No if the requirement is not satisfied by that prototype. Again, the cells turn green and red, respectively. In addition to this testing, there is space for a more detailed testing procedure, if relevant, and data, if relevant. There is more space for procedures and data on the 'Additional Data and Procedures' tab. Finally, there is room for a student to consider whether or not a new requirement needs to be added based on the prototype and testing results. If a new requirement is needed, the student returns back to the 'Identify \& Understand' tab to add the new requirement. 


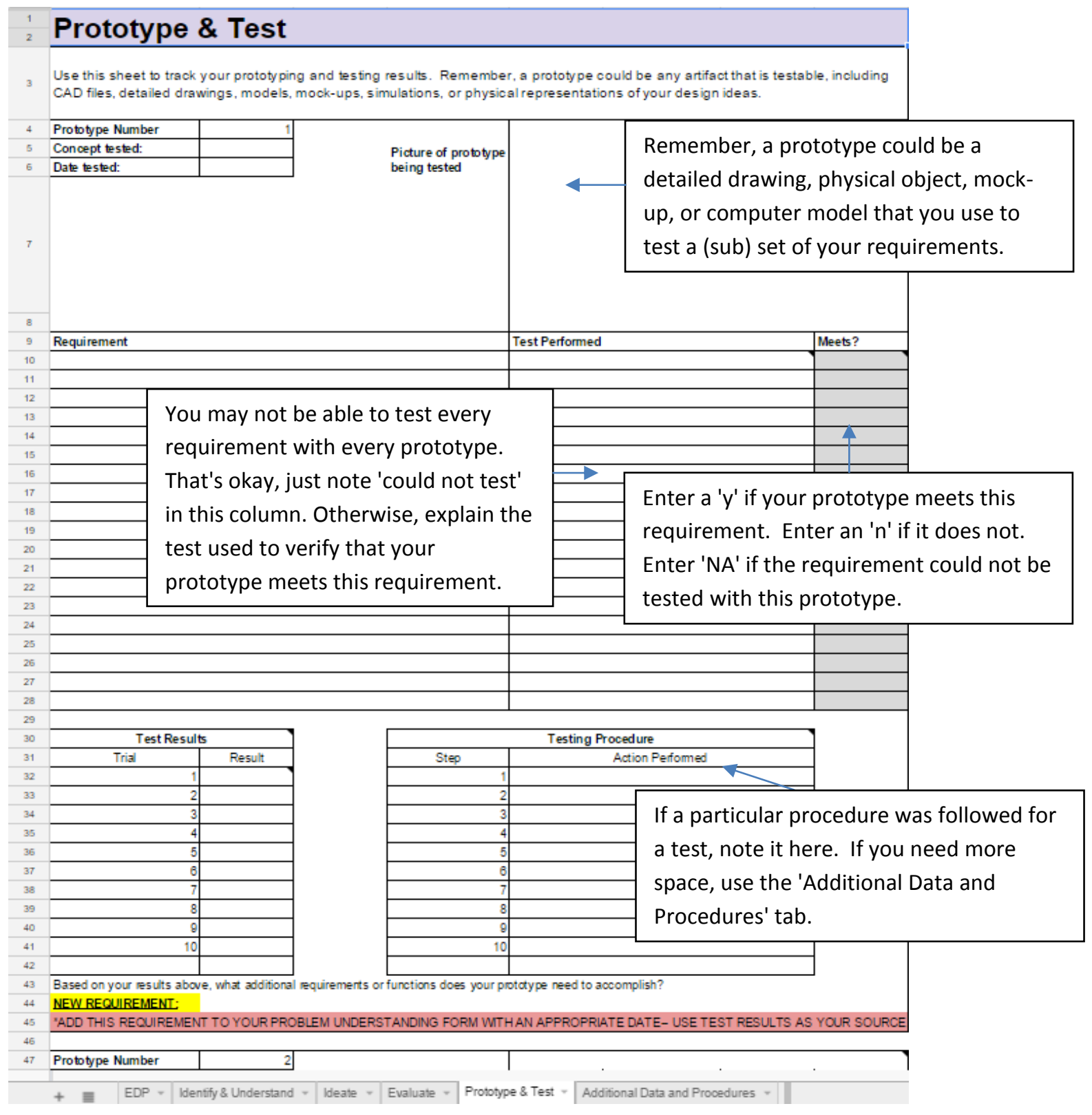

Figure 5: EDP Log, Prototype \& Test

Detailed expectations for each step of the EDP are laid out in the rubrics presented in Appendices A \& B. The rubrics specify in detail what the EDP logs should include for various levels of proficiency. It is important to note that the EDP log is designed for student growth; it is not intended to be mastered in a single use. Examples of some of the tabs filled out by $8^{\text {th }}$ grade students are provided in the Results section.

In the next section, we review the data collected from both the teachers and students regarding EDP log usage, successes, challenges, and assessment. 


\section{Data Sources}

Teacher Interviews: To examine the use of engineering logs, four Middle School (MS) and two High School (HS) technology \& engineering teachers were interviewed at the end of the fall semester, 2015. Two MS and one HS teachers had prior experience implementing the AMPIT-UP curriculum and EDP log. As part of the curriculum, all MS and HS students were expected to maintain an electronic engineering design process (EDP) log. All four middle schools used the same engineering curriculum for each grade level, and both high schools implemented the same first year engineering course. The interview protocol was designed to provide different perspectives from teachers about how the EDP logs were utilized. Additionally, teachers provided their perspectives about the benefits of EDP to their teaching, and challenges of the implementation. The interviews were semi-structured and lasted from 30 to 40 minutes. Interview results were analyzed using thematic analysis, which is defined as a process-oriented approach that involves using a systematic technique of identifying and coding themes ${ }^{24}$. At the conclusion of this pattern-finding process, the teacher perceptions of the utility purpose of the engineering notebooks in each of the participating schools were summarized.

Scoring rubric: Student EDP logs were assessed using a scoring rubric made up of elements (i.e., rubric domains) that correspond to the stages of the design process used in the curriculum. The rubric for the EDP log was adapted from the Engineering Design Process Portfolio Scoring Rubric ${ }^{25}$. The EDPPSR was developed as part of a National Science Foundation (NSF) grant whose purpose was to develop a scoring system that could be used to distinguish among student performance levels on engineering design projects ${ }^{26}$. The rubric is currently used as the end-of-course assessment for the capstone Engineering Design and Development (EDD) course from Project Lead the Way ${ }^{27}$. Additional details about the history of the original EDPPSR instrument are provided by Goldberg ${ }^{28}$.

The EDPPSR was revised in order to obtain an instrument that is aligned with the AMP-IT-UP high school curriculum and is appropriate for describing student achievement at the high school level. Whereas the original EDPPSR included 14 individual scoring elements, the rubric for the EDP log includes eight elements that correspond to the stages of the design process used in the course: A) Identify the Problem; B) Understand; C) Ideate; D) Evaluate; E) Prototype and Test; F) Iteration; G) Progression; and H) Communicate your Solution. Each element was scored using a rating scale with six categories in high school ( 5 = Exemplary; 4 = Advanced; $3=$ Proficient; $2=$ Developing; 1 = Novice; 0 = No evidence), and five categories in middle school ( 4 = Advanced; 3 $=$ Proficient $; 2=$ Developing; $1=$ Novice; $0=$ No evidence). The performance level descriptors for elements A through $\mathrm{G}$ were adapted from similar elements in the original instrument. The performance level descriptors for element $\mathrm{H}$ (Communicate your Solution) were developed in collaboration with the current high school instructors for the high school course. In order to facilitate completion of the log and understanding of the scoring scheme, students were provided with a checklist that highlighted the major components of the project on which their work would 
be evaluated. The full rubric and guidelines for proficiency are given for high school in Appendix A and middle school in Appendix B.

After students completed the EDP log, their work was evaluated using the scoring rubric. A member of the research team scored the process logs.

\section{Teachers' Perspectives on EDP Log}

Utilization: The MS teachers described significant variation in their implementation of the EDP log in their classrooms. Only one MS teacher's utilization of the log appeared to be completely in-line with what was expected, which was for students to complete individual logs for each challenge. Other teachers altered the utilization of the logs in unique ways. In order to help the younger students correctly complete the logs, one teacher implemented the logs as a teacher-led classroom activity. Another teacher had his students complete a single log that was continually augmented across the semester. The final teacher described a slow cessation of the use of the $\log$ as the semester progressed, primarily due to the challenges his students were having completing it correctly.

The HS teachers also described variations of the implementation of the EDP log. Similar to some of the MS teachers, HS teachers also implemented the logs as a teacher-led classroom activity.

Benefits: Both MS and HS teachers were asked about benefits that they perceived for the students from the use of the EDP Logs. Across interviews, MS teachers expected the logs to improve their students' organization and documentation skills. Both HS teachers expressed that it helped students to track their progress in the class. Two MS teachers stated that they hoped students would be able to use the log to inform design decisions during subsequent classes. All teachers also saw the benefit of additional exposure to the EDP process and the illustration of the process that the logs provided. Regarding contribution of the log to understanding specific EDP stages, all four MS teachers described the "Identify the Problem" and "Understand" stages specifically in helping students identify the problem statement and to specify the requirements. Additionally, one MS and one HS teacher explained that the log helped with the Ideate stage by providing the students with multiple designs to consider.

One HS teacher discussed multiple benefits of the logs for student learning. The EDP log allowed the whole process to be checked for errors; it allowed the design process to be replicated; and it allowed students to be able to go back and review their log to remember things that were learned earlier in the semester. Lastly, one HS teacher also pointed out that it contributed to the development of students' problem solving skills.

Challenges: Both HS and MS teachers described student resistance to the logs, though the perceived reasons for the resistance differed. One MS teacher ascribed the resistance to a lack of student understanding of the purpose of the log, for which the teacher took responsibility. Another MS teacher pointed out his own misunderstanding of how the log was to be implemented 
(having students keep a single log across all projects). Lastly, both a HS and MS teacher described the general difficulty of the log, particularly for lower ability students who struggled with reading, writing, and critical thinking requirements. Additionally, both teachers perceived students to be resistant to the amount of work/effort that was required.

The primary source of resistance that the HS teachers pointed out was that EDP logs were not applicable to all challenges because not all challenges included all of the steps of the EDP. This lack of alignment at certain points in the course confused students regarding the necessity of including all steps as part of the design process. One MS teacher also noted this challenge, though it was not described to be as significant of a problem, likely due to differences between the middle school and high school curricula.

Another difficulty that was highlighted by one HS and one MS teacher was due to the disruption that the electronic version of the log introduced into classroom activities, particularly when requiring students to transition from data collection activities using paper and pencil to completing reflections on the laptop. One high school teacher addressed this problem by having his students keep notes in paper format and then transfer to the electronic version.

Both MS and HS teachers identified several additional challenges that students faced when completing the logs. Across interviews, teachers commonly described technical challenges, particularly with working with digital images, which required multiple steps to move from the design software $\left(\operatorname{IronCad}^{29}\right)$ into the log. Lack of familiarity with Google Sheets was also identified as a challenge for some students, particularly among younger students $\left(6^{\text {th }}\right.$ grade $)$ who would accidentally delete headings while filling in text fields. This challenge was also described by a HS teacher as a barrier to implementing the EDP logs for those students not familiar with using the electronic format. In one HS classroom, some students also had challenges with InkScape ${ }^{30}$, mainly because the outputted files must be converted to a format that Google Sheets can recognize rather than an InkScape file.

Beyond the technical challenges, several MS teachers described the higher-level cognitive abilities that were required for successful completion of the logs. These challenges began with difficulty reading and following instructions, attributed to poor reading comprehension and listening skills. One teacher also attributed this challenge to the students' expectation that teachers will tell them what to do, therefore, thorough reading of the instructions was deemed unnecessary. Teachers also linked this perspective among students to their lack of familiarity with self-directed courses, particularly among younger $\left(6^{\text {th }}\right.$ grade $)$ students.

\section{EDP Log Rubric Results \& Sample Artifacts}

For this study, 20 EDP Logs from an $8^{\text {th }}$ grade class were scored by a research team member using the middle school rubric provided in Appendix B. The results are shown in aggregate in Table 1, below. 
On a scale ranging from 0 to 3 , the top score achieved on any element by any student was a 2 . The average score for the whole log was generally less than one, with two students achieving an average score greater than one across the elements. Because the EDP Log is intended to foster student growth, this is not unexpected. Zeroes are given for incomplete or missing elements. Most students achieved an average score of less than 1 for each of the elements, with the weakest elements being 'Prototype \& Test', 'Iterate', and 'Progression.' This is because achieving credit in these areas is largely dependent on a student having engaged in at least one design iteration; that is, they tested more than one prototype and have reflections that align with their decisions. Frequently, classroom deadlines and supply limitations curtail iteration. In addition, students may start off stronger in filling out the EDP logs, and their efforts may diminish as they start building their prototypes or lose interest in the project.

Table 1. Portfolio Ratings: Descriptive Statistics for Middle School Logs, Max Score $=3, n=20$

\begin{tabular}{|l|r|r|r|}
\hline \multicolumn{1}{|c|}{ Element* } & Mean & \multicolumn{1}{c|}{ SD } & Range (Min, Max) \\
\hline A: Identify the problem & 0.8 & 0.89 & $(0,2)$ \\
\hline B: Understand & 0.85 & 0.67 & $(0,2)$ \\
\hline C: Ideate & 1.15 & 0.67 & $(0,2)$ \\
\hline D: Evaluate & 0.75 & 0.85 & $(0,2)$ \\
\hline E: Prototype \& test & 0.25 & 0.44 & $(0,1)$ \\
\hline F: Iterate & 0.05 & 0.22 & $(0,1)$ \\
\hline G: Progression & 0.05 & 0.22 & \\
\hline
\end{tabular}

* Element $\mathrm{H}$ : Communicate your solution was not scored.

In addition to the descriptive statistics provided in Table 1, some examples of student work from the same $8^{\text {th }}$ grade class are shown in Figures 6-8. 


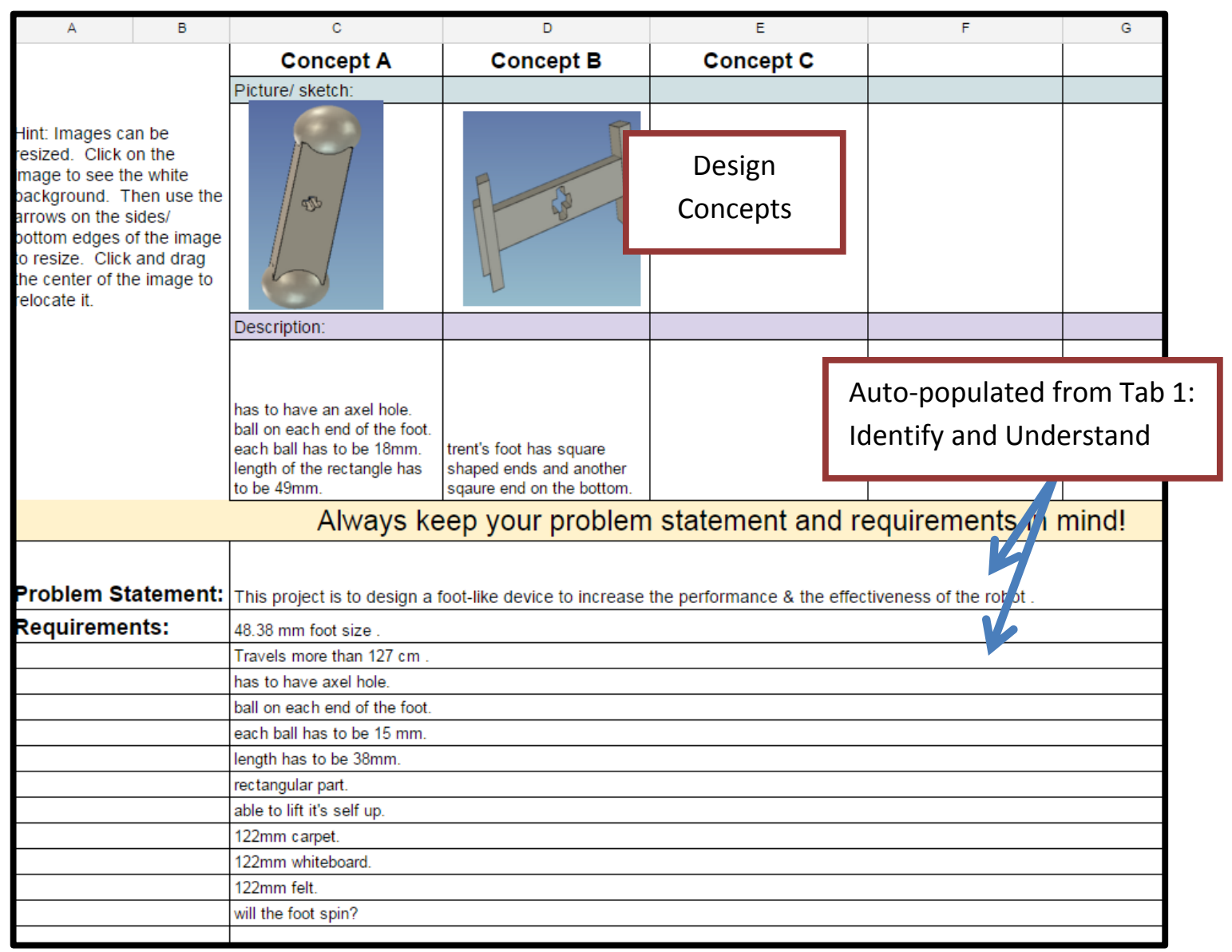

Figure 6: Example Ideate tab from EDP Log ( $8^{\text {th }}$ Grade) 


\begin{tabular}{|c|c|c|c|c|c|}
\hline 2 & \multicolumn{5}{|l|}{ Evaluate } \\
\hline 3 & \multicolumn{5}{|c|}{$\begin{array}{l}\text { At each itreation of the process, evaluate all current design concepts with respect to your list of re } \\
\text { Problem ID \& Understanding tab. For each requirement, enter and 'L' if you believe a design is lil } \\
\text { meet that requirement. The box will turn green or red, depending on your selection. Look for de: } \\
\text { your predictions are wrong-- just use this as a guide to help you decide which designs you think : }\end{array}$} \\
\hline 4 & & & & & \\
\hline \multirow[b]{2}{*}{6} & & Concept A & Concept B & Concept C & Concept D \\
\hline & Requirements: & $\begin{array}{l}\text { well this meets the } \\
\text { standards, but it is } \\
\text { not certainly in the } \\
\text { shape of and } X \text { so } \\
\text { there for this one } \\
\text { will not work. }\end{array}$ & $\begin{array}{l}\text { This product meets the } \\
\text { standards but does not } \\
\text { have the inserts on the } \\
\text { ends. I have to go back } \\
\text { and add the inserts on } \\
\text { the ends of the axel } \\
\text { wheel }\end{array}$ & $\begin{array}{l}\text { This is the last design i } \\
\text { created. it completes all } \\
\text { of the standards and } \\
\text { also has all of the axel } \\
\text { holes, end inserts and is } \\
\text { in the shape of an X. }\end{array}$ & \\
\hline 7 & must be smaller than $100 \mathrm{~mm}$ & 1 & u & 1 & \\
\hline 8 & $\begin{array}{l}\text { needs to be in the shape of } \\
\text { an X }\end{array}$ & 1 & 1 & 1 & \\
\hline 9 & have an axel hole & $\mathrm{u}$ & 1 & 1 & \\
\hline 10 & $\begin{array}{l}\text { just to meet all of the } \\
\text { requiremnets }\end{array}$ & $\mathrm{u}$ & u & 1 & \\
\hline \multicolumn{6}{|l|}{11} \\
\hline \multicolumn{6}{|l|}{12} \\
\hline \multicolumn{6}{|l|}{13} \\
\hline \multicolumn{6}{|l|}{14} \\
\hline 15 & & & & & \\
\hline
\end{tabular}

\section{Figure 7: Example Evaluate tab from EDP Log ( $8^{\text {th }}$ Grade)}

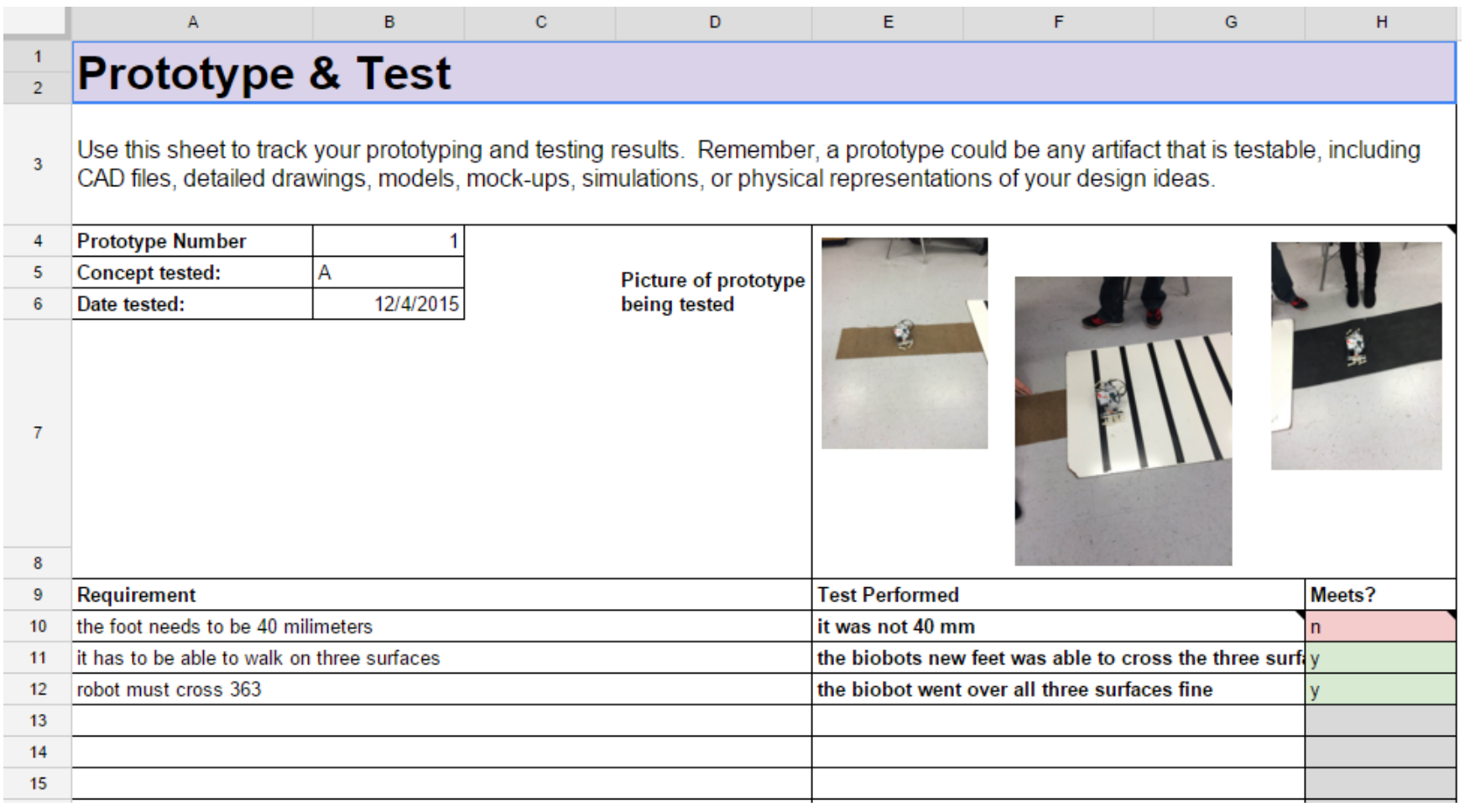

Figure 8: Example Prototype \& Test tab from EDP Log $\left(8^{\text {th }}\right.$ Grade $)$ 


\section{Revisions and Curricular Impacts}

The EDP Log has been revised based on teacher feedback and student data. The choice to use an electronic platform followed the implementation of a paper-based version in a prior year. The paper portfolios were not useful for grading by the teachers and were not yielding any meaningful research data. Even storing the notebooks in the classroom proved to be a logistical challenge. Implementing the EDP log electronically alleviates many of those issues, though it too is not a perfect solution, as discussed in the results from teacher interviews.

More importantly, the EDP Log required some revisions to the course curriculum and professional development. The researchers found that teachers were more likely to engage with the EDP log if it was explicitly referenced in the teacher-facing curriculum materials. On the other hand, the EDP log is not always relevant to the different projects contained within the curriculum. This finding forced the authors to consider whether each project was truly a design project; some projects are actually intended for skill-building and do not readily lend themselves to the EDP log paradigm.

In terms of professional development, the researchers and curriculum developers found that it was necessary to have professional development specifically focused on the EDP log. Because it is possible to engage in the curriculum activities without engaging with the log, it is not safe to assume that log usage is intuitive. Ideally, log usage is what keeps the students and teachers focused on the process of performing engineering and prevents students from losing perspective during the specific steps of the process. In order for students and teachers to recognize the patterns inherent in following a systematic engineering process, it is important to continually tie the projects back to the specific steps of the EDP.

An open issue facing the EDP log developers is the documentation of reflections. The original EDP log contained a tab for reflection, but because Google Sheets and Excel are not intended for word processing, students were losing their work by clicking out of cells or not clicking into the text editor. To counter that, it was suggested that teachers have students keep an accompanying word processor file (Microsoft Word or Google Doc) containing dated reflections; however, having to switch between two different documents is a hindrance to students completing both the $\log$ and the reflections.

\section{Conclusions and Future Work}

While many agree that there are many benefits to keeping an engineering notebook, there is a lack of clarity as to what an engineering notebook should contain and why it should be kept ${ }^{5}$. In addition, past design notebooks have often favored only a single step of the design process ${ }^{10}$. The EDP Log is an attempt at distilling and crystallizing some of the key design process elements for all steps of the EDP in a way that is tractable for both teachers and students. 
To be successful in implementing any engineering notebook paradigm, it is important that the teachers understand the pedagogical and assessment value of using an engineering design log or notebook and make the purpose and expectations clear to the students. This is consistent with the literature, which reinforces the belief that it is difficult for students to engage in record keeping and to see value in that activity.

As noted in the discussion on revisions and curriculum implications, the reflective aspects of the EDP log still need to be improved. It is difficult to get students to self-reflect and self-evaluate, and even more difficult to get students to document those reflections in a meaningful way. While the EDP log is designed to consolidate a lot of the writing and documentation efforts, it is not intended to replace reflection, rather to supplement it. Developing this practice in the classroom and supporting it from the documentation and technology side is an ongoing challenge.

While the EDP Log is deceptively simple, each step is non-trivial in its execution, and the process is open-ended. With continued feedback, updates, revisions, and professional development, we hope to see continued growth in the teachers' engagement with the EDP log and rubrics as well as growth in student work for the remaining two years of implementation for the AMP-IT-UP grant.

\section{Acknowledgements}

This work has been funded by National Science Foundation Award 1238089, Advanced Manufacturing and Prototyping Integrated to Unlock Potential (AMP-IT-UP).

\section{References}

1. Singhose W and Donnell J. Introductory Mechanical Design Tools. Department of Mechanical Engineering, Georgia Institute of Technology, 2009.

2. Engineering Design Process, http://www.teachengineering.org/engrdesignprocess.php, January 4, 2014.

3. NGSS Lead States. Next Generation Science Standards: For States, By States. Washington, DC: The National Academies Press, 2013.

4. $\quad$ Eris O. Insisting on truth at the expense of conceptualization: Can engineering portfolios help? International Journal of Engineering Education. 2006; 22: 551-9.

5. Kelly TR. Engineer's notebook - a design assessment tool. Technology and Engineering Teacher. 2011; April, 2011: 30-5.

6. Kelly TR. Construction of an engineer's notebook rubric. Technology and Engineering Teacher. 2014; February, 2014: 26-32.

7. Sadler PM, Coyle HP and Schwartz M. Engineering competitions in the middle school classroom: Key elements in developing effective design challenges. The Journal of the Learning Sciences. 2000; 9: 299-327.

8. Shackelford RL. Student portfolios: A process/product learning and assessment strategy. The Technology Teacher. 1996; May/June 1996: 31-6. 
9. Mehalik MM, Doppelt Y and Schunn CD. Middle-school science through design-based learning versus scripted inquiry: Better overall science concept learning and equity gap reduction. Journal of Engineering Education. 2008; January, 2008: 71-85.

10. Berland LK, McKenna WF and Peacock SB. Understanding students' perceptions on the utility of engineering notebooks. 118th ASEE Annual Conference and Exposition. Vancouver, B.C. Canada2011.

11. Lawanto O. Understanding of student task interpretation, design planning, and cognitive strategies during engineering design activities in Grades 9-12. National Center for Engineering and Technology Education, 2011.

12. Finkel E. Making sense of genetics: Students' knowledge use during problem solving in a high school genetics class. Journal of Research in Science Teaching. 1996; 33: 345-68.

13. Beer RD, Chiel HJ and Drushel RF. Using autonomous robotics to teach science and engineering. Communications of the ACM. 1999; 42: 85-92.

14. Svarovsky GN and Shaffer DW. Design meetings and design notebooks as tools for reflection in the engineering design course. 36th ASEE/IEEE Frontiers in Education Conference. San Diego, CA2006.

15. Jaeger $\mathrm{M}$ and Adair D. Using an evidential reasoning approach for portfolio assessments in a project-based learning engineering design course. European Journal of Engineering Education. 2015; 40: 638-52.

16. Moore RA, Alemdar M, Newton SH, Rosen JH, Usselman M and Wind SA. High School Engineering Class: From Wood Shop to Advanced Manufacturing. 2015 ASEE Annual Conference and Exposition. Seattle, Washington 2015.

17. Davis DC, Gentili KL, Trevisan MS and Calkins DE. Engineering Design Assessment Processes and Scoring Scales for Program Improvement and Accountability. Journal of Engineering Education. 2002; 91: 211-21.

18. Fahrer NE, Ernst JV and Branoff TJ. Performance and Cognitive Assessment in 3-D Modeling. Journal of STEM Teacher Education. 2011; 48: 68-95.

19. Groves JF, Abst LR and Goldberg GL. Using and Engineering Design Process Portfolio Scoring Rubric to Structure Online High School Engineering Education. 121st ASEE Conference \& Exposition. Indianapolis, IN2014.

20. Householder DL and Hailey CE. Incorporating Engineering Design Challenges into STEM courses. National Center for Engineering and Technology Education, 2012.

21. Kelley TR and Wicklein RC. Examination of Assessment Practices for Engineering Design Projects in Secondary Technology Education. Journal of Industrial Teacher Education. 2009; 46: 6-25.

22. Asunda PA and Hill RB. Critical Features of Engineering Design in Technology Education. Journal of Industrial Teacher Education. 2007; 44: 25-48.

23. Schubert TF, Jacobitz FG and Kim EM. Student Perceptions and Learning of the Engineering Design Process: An Assessment at the Freshman Level. Research in Engineering Design. 2012; 23: $177-90$.

24. Boyatzis RE. Transforming qualitative information: Thematic analysis and code development. London, \& New Delhi: SAGE Publications, 1998. 
25. Goldberg GL. Engineering Design Process Portfolio Scoring Rubric (EDPPSR): Scoring Pilor Final Report. College Park, MD: University of Maryland, 2011.

26. National Science Foundation. Research spending \& results award detail: Award number 1118755. 2011.

27. Engineering Asssessment: Assessment for learning and of learning, https://www.pltw.org/ourprograms/engineering/engineering-assessment, January 14.

28. Goldberg GL. Revising an engineering design rubric: A case study illustrating principles and practices to ensure technical quality of rubrics. Practical Assessment, Research, \& Evaluation. 2014; 19: 1-12.

29. IronCAD, http://www.ironcad.com/index.php/products/ironcad, January 30, 2015.

30. Inkscape, https://inkscape.org/en/, January 30, 2015. 


\section{Appendix A: High School Rubric for Engineering Design Logs}

Element A: Identify the Problem

\begin{tabular}{|c|c|l|}
\hline $\begin{array}{c}\text { Score } \\
\text { Point }\end{array}$ & $\begin{array}{c}\text { Performance } \\
\text { Level }\end{array}$ & \multicolumn{1}{c|}{ Performance Level Description } \\
\hline 5 & Exemplary & $\begin{array}{l}\text { The problem is clearly and objectively identified and defined with considerable } \\
\text { depth, and it is well elaborated with specific detail. The problem statement } \\
\text { should indicate a clear need and an intended client or market. The problem } \\
\text { statement should not propose a particular design solution. }\end{array}$ \\
\hline 4 & Advanced & $\begin{array}{l}\text { The problem is clearly and objectively identified and defined with some depth, } \\
\text { and it is generally elaborated with specific detail. The problem statement should } \\
\text { indicate a clear need, but the market identified may be imprecise. The problem } \\
\text { statement should be solution agnostic. }\end{array}$ \\
\hline 3 & Proficient & $\begin{array}{l}\text { The problem is somewhat clearly and objectively identified and defined with } \\
\text { adequate depth, and it is sometimes elaborated with specific detail, although } \\
\text { some information intended as elaboration may be imprecise or general. The } \\
\text { problem statement may lack either a clear need or a clear market or client. The } \\
\text { problem statement may imply a certain solution or class of solutions. }\end{array}$ \\
\hline 2 & Developing & $\begin{array}{l}\text { The problem is identified only somewhat clearly and/or objectively and defined } \\
\text { in a manner that is somewhat superficial and/or minimally elaborated with } \\
\text { specific detail. The problem statement may be a paraphrase of a given problem } \\
\text { statement, but does not indicate further analysis of the need or intended market. } \\
\text { The problem statement may favor a particular solution. }\end{array}$ \\
\hline 1 & Novice & $\begin{array}{l}\text { The identification and/or definition of the problem is unclear, is unelaborated, } \\
\text { and/or is clearly subjective. The problem statement may imply the solution } \\
\text { without a clear illustration of the need or the client. }\end{array}$ \\
\hline 0 & No Evidence & $\begin{array}{l}\text { The identification and/or definition of the problem are missing OR cannot be } \\
\text { inferred from information included. }\end{array}$ \\
\hline
\end{tabular}

Guidelines for Proficiency:

- I described the exact problem clearly, including a need and a client or market.

- My description of the problem is not biased toward any one solution.

- My description of the problem includes information about the background, context, or setting for the problem. 


\begin{tabular}{|c|c|c|}
\hline $\begin{array}{l}\text { Score } \\
\text { Point }\end{array}$ & $\begin{array}{c}\text { Performance } \\
\text { Level }\end{array}$ & Performance Level Description \\
\hline 5 & Exemplary & $\begin{array}{l}\text { Design requirements are listed with dates that indicate when they were added to the list } \\
\text { along with an appropriate source. The sources for the requirements should provide clear } \\
\text { justification for why the requirement was added. The requirements are consistently clear } \\
\text { and detailed, objective, measurable, and they would be highly likely to lead to a } \\
\text { tangible and viable solution to the problem identified; there is evidence that } \\
\text { requirements represent the needs of the client or customer. The sources for the } \\
\text { requirements are logical and include evidence of market research as well as testing of } \\
\text { initial prototypes. }\end{array}$ \\
\hline 4 & Advanced & $\begin{array}{l}\text { Design requirements are listed with dates that indicate when they were added to the list } \\
\text { along with an appropriate source. The requirements are generally clear and detailed, } \\
\text { nearly always objective and measurable, and they would be likely to lead to a tangible } \\
\text { and viable solution to the problem identified; there is evidence that requirements } \\
\text { represent the needs of the client or customer. The sources for the requirements are logical } \\
\text { and generally include evidence of market research and testing of initial prototypes. }\end{array}$ \\
\hline 3 & Proficient & $\begin{array}{l}\text { Design requirements are listed with dates that indicate when they were added to the list, } \\
\text { and generally include an appropriate source. The requirements are generally clear and } \\
\text { somewhat detailed, generally objective and measurable, and they have the potential to } \\
\text { lead to a tangible and viable solution to the problem identified. There is evidence that } \\
\text { requirements represent the needs of the client or customer. The sources for the } \\
\text { requirements are logical, and at least a few include evidence of market research and } \\
\text { testing of initial prototypes. Some requirements may be solution specific. }\end{array}$ \\
\hline 2 & Developing & $\begin{array}{l}\text { Design requirements are listed with dates that indicate when they were added to the list } \\
\text { along with meaningful sources for most of the requirements. Some/all of these } \\
\text { requirements may be incomplete and/or lack specificity; these design requirements } \\
\text { may be only sometimes objective and/or measurable, and it is not clear that they will } \\
\text { lead to a tangible and viable solution to the problem identified. There is some evidence } \\
\text { that the requirements represent the needs of the client or customer. The sources for the } \\
\text { requirements may be insufficient, outdated, or of dubious credibility. There may not be } \\
\text { evidence of market research and testing of initial prototypes. }\end{array}$ \\
\hline 1 & Novice & $\begin{array}{l}\text { An attempt is made to list, format, and document research for requirements, but these } \\
\text { generally do not include meaningful sources. The requirements may be partial and/or } \\
\text { overly general, making them insufficiently measurable to support a viable solution to } \\
\text { the problem identified. There is no evidence that the requirements represent the needs of, } \\
\text { or the client or customer. The sources for the requirements are overly general, outdated, } \\
\text { and/or of dubious credibility. There is no evidence of market research or testing of } \\
\text { initial prototypes. }\end{array}$ \\
\hline 0 & No Evidence & $\begin{array}{l}\text { Design requirements are either not presented or are too vague to be used to outline the } \\
\text { measurable attributes of a possible design solution to the problem identified. } \\
\text { Documentation of research to support the requirements do not include sources, and is } \\
\text { essentially only the opinion of the researcher. There is no evidence of market research } \\
\text { or testing of initial prototypes. }\end{array}$ \\
\hline
\end{tabular}

Note: The level of requirements that a student provides differentiates between the levels. Additionally, if there are no sources (marketing research etc.), rater should begin no higher than "Developing" level.

\section{Guidelines for Proficiency:}


- I listed a set of design requirements (measureable things that a design would have to accomplish in order to be seen as a real solution).

- I indicated the date on which each design requirement was added to the list.

- I described the research that I conducted for each design requirement. For example, this might include background research or market research.

- I included a source for each design requirement, such as a client, user, background research, or test results. 
Element C: Ideate

\begin{tabular}{|c|c|c|}
\hline $\begin{array}{l}\text { Score } \\
\text { Point }\end{array}$ & \begin{tabular}{|c|}
$\begin{array}{c}\text { Performance } \\
\text { Level }\end{array}$ \\
\end{tabular} & Performance Level Description \\
\hline 5 & Exemplary & $\begin{array}{l}\text { The process for generating possible design solutions was comprehensive, } \\
\text { iterative, and consistently defensible, making a viable and well-justified design } \\
\text { highly likely. Multiple sketches for potential solutions were provided; the } \\
\text { sketches were clear and provided sufficient detail to communicate each design. }\end{array}$ \\
\hline 4 & Advanced & $\begin{array}{l}\text { The process for generating possible design solutions was thorough, iterative, and } \\
\text { generally defensible, making a viable design likely. Multiple sketches for } \\
\text { potential solutions were provided; the sketches generally provided sufficient } \\
\text { detail to communicate each design. }\end{array}$ \\
\hline 3 & Proficient & $\begin{array}{l}\text { The process for generating possible design solutions was adequate and generally } \\
\text { iterative and defensible, making a viable design possible. Multiple sketches for } \\
\text { potential solutions were provided; the sketches provided some detail to } \\
\text { communicate each design. }\end{array}$ \\
\hline 2 & Developing & $\begin{array}{l}\text { The process for generating a possible design solution was partial or overly } \\
\text { general and only somewhat iterative and/or defensible, raising issues with the } \\
\text { viability of the design solution chosen. One or more sketches for potential } \\
\text { solutions were provided; the sketches were general and provided partial details } \\
\text { about each design. }\end{array}$ \\
\hline 1 & Novice & $\begin{array}{l}\text { The process for generating a possible design solution was incomplete and was } \\
\text { only minimally iterative and/or defensible. One or more sketch for a potential } \\
\text { solution may have been provided and/or the sketches included insufficient detail } \\
\text { to communicate each design. }\end{array}$ \\
\hline 0 & No Evidence & $\begin{array}{l}\text { There is no evidence of an attempt to arrive at a design solution through an } \\
\text { iterative process based on design requirements. No sketches for potential } \\
\text { solutions were provided. }\end{array}$ \\
\hline
\end{tabular}

Note: Student should provide more than one concept, should provide multiple ideas, and should not be merely justifying one preferred idea.

Guidelines for Proficiency:

- I sketched multiple potential solutions.

- My sketches provided sufficient detail to communicate each design. (e.g.: defining main futures such as functions and materials) 
Element D: Evaluate

\begin{tabular}{|c|c|c|}
\hline $\begin{array}{l}\text { Score } \\
\text { Point }\end{array}$ & $\begin{array}{l}\text { Performance } \\
\text { Level }\end{array}$ & Performance Level Description \\
\hline 5 & Exemplary & $\begin{array}{l}\text { Students used a decision tool to rate each of their potential design solutions. The } \\
\text { process for comparing possible designs solutions based on strengths and } \\
\text { weaknesses was comprehensive, iterative, and consistently defensible. The design } \\
\text { solution ultimately chosen was well justified and demonstrated attention to all } \\
\text { design requirements. }\end{array}$ \\
\hline 4 & Advanced & $\begin{array}{l}\text { Students used a decision tool to rate each of their potential design solutions. The } \\
\text { process for comparing possible designs solutions based on strengths and } \\
\text { weaknesses was thorough, iterative, and generally defensible. The design solution } \\
\text { chosen was justified and demonstrated attention to most if not all design } \\
\text { requirements. }\end{array}$ \\
\hline 3 & Proficient & $\begin{array}{l}\text { Students used a decision tool to rate each of their potential design solutions. The } \\
\text { process for comparing possible designs solutions based on strengths and } \\
\text { weaknesses was thorough, iterative, and generally defensible. The choice of } \\
\text { design solution was explained with reference to at least some design } \\
\text { requirements. }\end{array}$ \\
\hline 2 & Developing & $\begin{array}{l}\text { Students may have used a decision tool to rate each of their potential design } \\
\text { solutions. The process for generating a possible design solution was partial or } \\
\text { overly general and only somewhat iterative and/or defensible, raising issues with } \\
\text { the viability of the design solution chosen; that solution was not explained with } \\
\text { reference to design requirements. }\end{array}$ \\
\hline 1 & Novice & $\begin{array}{l}\text { The proposed design was superficially reviewed based on one or two } \\
\text { considerations. The choice of design solution lacked support related to design } \\
\text { requirements. }\end{array}$ \\
\hline 0 & No Evidence & $\begin{array}{l}\text { There is no evidence provided that a design solution was reviewed through an } \\
\text { iterative process based on design requirements. }\end{array}$ \\
\hline
\end{tabular}

Note: Starting from this stage the rater should start reviewing the reflection section. Student should provide more than one concept, should provide multiple ideas, and should not be merely justifying one preferred idea.

\section{Guidelines for Proficiency:}

- I evaluated each of my possible solutions with respect to the design requirements.

- My reflections included explanations how I evaluated each requirement.

- I described the strengths and weaknesses of each design.

- I used a decision tool to rate the designs.

- I described the solution that I decided to test, and described why I thought it was the best one to try based on the requirements. 
Element E: Prototyping and Testing

\begin{tabular}{|c|c|c|}
\hline $\begin{array}{l}\text { Score } \\
\text { Point }\end{array}$ & \begin{tabular}{|c|}
$\begin{array}{c}\text { Performance } \\
\text { Level }\end{array}$ \\
\end{tabular} & Performance Level Description \\
\hline 5 & Exemplary & $\begin{array}{l}\text { The final prototype iteration is clearly and fully explained and is constructed } \\
\text { with enough detail to assure that all or nearly all design requirements could be } \\
\text { tested. A well-supported justification is provided for the requirements that } \\
\text { cannot be tested or modeled mathematically and thus require expert review or } \\
\text { further prototyping that is not currently feasible. }\end{array}$ \\
\hline 4 & Advanced & $\begin{array}{l}\text { The final prototype iteration is clearly and adequately explained and is } \\
\text { constructed with enough detail to assure that many design requirements could be } \\
\text { tested. A generally supported justification is provided for the requirements that } \\
\text { cannot be tested or modeled mathematically and thus require expert review or } \\
\text { further prototyping that is not currently feasible. }\end{array}$ \\
\hline 3 & Proficient & $\begin{array}{l}\text { The final prototype iteration is clearly and adequately explained and is } \\
\text { constructed with enough detail to assure that some design requirements could be } \\
\text { tested. An adequately supported justification is provided for the requirements } \\
\text { that cannot be tested or modeled mathematically and thus require expert review or } \\
\text { further prototyping that is not currently feasible. }\end{array}$ \\
\hline 2 & Developing & $\begin{array}{l}\text { The final prototype iteration is explained only somewhat clearly and/or } \\
\text { completely and is constructed with enough detail to assure that at least a few } \\
\text { design requirements could be tested. There may be insufficient justification for } \\
\text { the requirements that cannot be tested or modeled mathematically and thus require } \\
\text { expert review or further prototyping that is not currently feasible. }\end{array}$ \\
\hline 1 & Novice & $\begin{array}{l}\text { The final prototype iteration is only minimally explained and/or is not } \\
\text { constructed with enough detail to assure that objective data on at least one design } \\
\text { requirement could be determined. Any attempt at justification for the } \\
\text { requirements that cannot be tested or modeled mathematically and thus require } \\
\text { expert review or further prototyping that is not currently feasible is missing. }\end{array}$ \\
\hline 0 & No Evidence & $\begin{array}{l}\text { Any attempt to explain the final prototype iteration is unclear or is missing } \\
\text { altogether. There is no evidence that the prototype would facilitate testing by } \\
\text { suitable means for any of the design requirements. }\end{array}$ \\
\hline
\end{tabular}

Note: In the logs, the iteration is embedded in this stage. There is no separate tab for iteration.

Guidelines for Proficiency:

- I created detailed technical drawings for my solution.

- Where possible, I created mathematical and computer models for the solution.

- I built a physical model of my solution.

- I showed that my design meets all of the design requirements. 
Element F: Iteration

\begin{tabular}{|c|c|c|}
\hline $\begin{array}{l}\text { Score } \\
\text { Point }\end{array}$ & $\begin{array}{c}\text { Performance } \\
\text { Level }\end{array}$ & Performance Level Description \\
\hline 5 & Exemplary & $\begin{array}{l}\text { The project designer provides a consistently clear, insightful, and comprehensive } \\
\text { reflection on, and value judgment of, each major step in the project; the reflection } \\
\text { includes a substantive summary of lessons learned that would be clearly useful to } \\
\text { others attempting the same or similar project. There is clear evidence of iteration in } \\
\text { the design concepts and prototypes. }\end{array}$ \\
\hline 4 & Advanced & $\begin{array}{l}\text { The project designer provides a clear, insightful and well-developed reflection } \\
\text { on, and value judgment of, each major step in the project; the reflection includes } \\
\text { a summary of lessons learned that would be clearly useful to others attempting the } \\
\text { same or similar project. There is clear evidence of iteration in either the design } \\
\text { concepts and/or prototypes. }\end{array}$ \\
\hline 3 & Proficient & $\begin{array}{l}\text { The project designer provides a generally clear and insightful, adequately- } \\
\text { developed reflection on, and value judgment of, major steps in the project, } \\
\text { although one or two steps may be addressed in a more cursory manner; the } \\
\text { reflection includes a summary of lessons learned, at least most of which would be } \\
\text { useful to others attempting the same or similar project. There is some evidence of } \\
\text { iteration in either design concepts or prototypes. }\end{array}$ \\
\hline 2 & Developing & $\begin{array}{l}\text { The project designer provides a generally clear, at least somewhat insightful, and } \\
\text { partially developed reflection on, and value judgment of, most if not all of the } \\
\text { major steps in the project; the reflection includes some lessons learned which } \\
\text { would be useful to others attempting the same or similar project. At least one } \\
\text { improvement was made to a design concept or prototype. }\end{array}$ \\
\hline 1 & Novice & $\begin{array}{l}\text { The project designer provides a reflection on, and value judgment of, at least some } \\
\text { of the major steps in the project, although the reflection may be partial, overly- } \\
\text { general and/or superficial; the reflection includes a few lessons learned of which at } \\
\text { least one would be useful to others attempting the same or similar project. There } \\
\text { may be no evidence of improvements or iteration, only reflections on what could be } \\
\text { improved in the future. }\end{array}$ \\
\hline 0 & No Evidence & $\begin{array}{l}\text { The project designer attempts a reflection on, and value judgment of, at least one } \\
\text { or two of the major steps in the project, although the reflection may be minimal, } \\
\text { unclear, and/or extremely superficial; any lessons learned are unclear and/or of no } \\
\text { likely use to others attempting the same or similar project; OR there is no evidence } \\
\text { of a reflection and/or lessons learned. There is no evidence of iteration or } \\
\text { improvement in the student design process. }\end{array}$ \\
\hline
\end{tabular}

Note: If the student does not provide more than one concept in the earlier stages, then iteration

evidence might not exist. Again, the reflection tab is important to review for this section.

Guidelines for Proficiency:

- I made clear improvements to my project through an iterative design process.

- I wrote a reflection about my design process for this problem.

- My reflection describes the decisions I made and why I made them.

- My reflection describes what I would do differently if I tried to address the problem again, or advice that I would give to someone else who was trying to address the problem. 
Element G: Progression

\begin{tabular}{|c|c|c|}
\hline $\begin{array}{l}\text { Score } \\
\text { Point }\end{array}$ & $\begin{array}{c}\text { Performance } \\
\text { Level }\end{array}$ & Performance Level Description \\
\hline 5 & Exemplary & $\begin{array}{l}\text { The portfolio provides consistently clear, detailed, and extensive documentation of the } \\
\text { design process and project that would with certainty facilitate subsequent replication and } \\
\text { refinement by the designer(s) and/or others; attention to audience and purpose was } \\
\text { abundantly evident in the choice of mode(s) of presentation, professionalism of style and } \\
\text { tone, and the variety, quality, and suitability of supporting materials. }\end{array}$ \\
\hline 4 & Advanced & $\begin{array}{l}\text { The portfolio provides clear, generally detailed and thorough documentation of the } \\
\text { design process and project that would be likely to facilitate subsequent replication and } \\
\text { refinement by the designer(s) and/or others; attention to audience and purpose was evident } \\
\text { in the choice of mode(s) of presentation, professionalism of style and tone, and the variety, } \\
\text { quality, and suitability of supporting materials. }\end{array}$ \\
\hline 3 & Proficient & $\begin{array}{l}\text { The portfolio provides generally clear and thorough documentation of the design process } \\
\text { and project that would be likely to facilitate subsequent replication and refinement by the } \\
\text { designer(s) and/or others, although there may be some minor omissions or inconsistencies; } \\
\text { attention to audience and purpose was generally-but not always--evident in the choice of } \\
\text { mode(s) of presentation, professionalism of style and tone, and the variety, quality, and } \\
\text { suitability of supporting materials. }\end{array}$ \\
\hline 2 & Developing & $\begin{array}{l}\text { The portfolio provides partial or sometimes overly general documentation of the design } \\
\text { process and project that would be unlikely to facilitate subsequent replication and } \\
\text { refinement by the designer(s) and/or others; attention to audience and purpose was only } \\
\text { sometimes/somewhat evident in the choice of mode(s) of presentation, professionalism of } \\
\text { style and tone, and the variety, quality, and suitability of supporting materials. }\end{array}$ \\
\hline 1 & Novice & $\begin{array}{l}\text { The portfolio provides minimal documentation of the design process and project that } \\
\text { would not facilitate subsequent replication and refinement by the designer(s) and/or } \\
\text { others; attention to audience and purpose was rarely evident in the choice of mode(s) of } \\
\text { presentation, professionalism of style and tone, and the variety, quality, and suitability of } \\
\text { supporting materials. The portfolio contains documentation of each step of the process, but } \\
\text { no iteration or improvement based on the design requirements; that is, the portfolio indicates } \\
\text { design fixation. }\end{array}$ \\
\hline 0 & No Evidence & $\begin{array}{l}\text { The portfolio attempts to document the design process and project but little/none of that } \\
\text { information supports subsequent replication and refinement by the designer(s) and/or } \\
\text { others; little/no attention to audience and purpose was evident in the choice of mode(s) } \\
\text { of presentation, professionalism of style and tone, or the variety, quality, and suitability of } \\
\text { any supporting materials included. The process as documented is linear, indicating early } \\
\text { design fixation and no subsequent improvements based on the design requirements. }\end{array}$ \\
\hline
\end{tabular}

Note: If only one concept is provided, there is not much evidence of progression.

Guidelines for Proficiency:

- My portfolio includes relevant documentation of each stage of the design process.

- My portfolio provides enough detail to guide someone else in following my procedure.

- My portfolio indicates that I followed a true engineering design process driven by customer needs and requirements, and that multiple solution candidates were considered and improved throughout the process. 
Element H: Communicate your Solution*

\begin{tabular}{|c|c|c|}
\hline $\begin{array}{l}\text { Score } \\
\text { Point }\end{array}$ & $\begin{array}{c}\text { Performance } \\
\text { Level }\end{array}$ & Performance Level Description \\
\hline 5 & Exemplary & $\begin{array}{l}\text { Content: Presentation communicates a design solution or product idea in an extremely clear } \\
\text { and compelling manner, exhibiting expertise on the solution being presented. Presentation } \\
\text { includes three or more types of data (financial, stakeholder, test results, research), ideally } \\
\text { visualized and analyzed, to justify design decisions and/or present a compelling sales pitch. A } \\
\text { designed solution is communicated clearly using at least two of the following: physical } \\
\text { prototypes, drawings, and renderings as appropriate. The presentation is audience appropriate. } \\
\text { For a sales pitch, relevant financial data is included. For a design review, relevant technical } \\
\text { details and models are included. } \\
\text { Skill: Presenter(s) spoke clearly with appropriate pace and pauses, made eye contact with the } \\
\text { audience, did not read off of slides, exhibited appropriate posture, kept audience engaged, and } \\
\text { adhered to the time limits. }\end{array}$ \\
\hline 4 & Advanced & $\begin{array}{l}\text { Content: Presentation communicates the topic in a clear and compelling manner, exhibiting a } \\
\text { high level of knowledge on the solution being presented. Presentation includes at least two } \\
\text { types of data (financial, stakeholder, test results, research) with appropriate analysis and } \\
\text { visualizations to justify design decisions and/or present a compelling sales pitch. A designed } \\
\text { solution is communicated using at least one of the following: physical prototypes, drawings, } \\
\text { and renderings, as appropriate. The presentation is audience appropriate. } \\
\text { Skill: Presenter(s) spoke clearly, did not read off of slides, and adhered to the time limits. }\end{array}$ \\
\hline 3 & Proficient & $\begin{array}{l}\text { Content: Presentation communicates the topic in a somewhat clear and compelling manner. } \\
\text { Presentation exhibits some use data to justify design decisions and/or present a compelling sales } \\
\text { pitch. There is some evidence of data analysis and visualization. A designed solution is } \\
\text { communicated using physical prototypes, drawings, and renderings, as appropriate, but some } \\
\text { details may not be clear. Presentation is mostly audience appropriate. } \\
\text { Skill: Presenter(s) adhered to the time limits and did not read off of slides. }\end{array}$ \\
\hline 2 & Developing & $\begin{array}{l}\text { Content: Presentation communicates a clear design solution or a clear use of data, but maybe } \\
\text { not both. The presentation contains some visual media and a description of the solution. The } \\
\text { presentation may not be tailored to the appropriate audience. } \\
\text { Skill: Presenter(s) adhered to the time limits. }\end{array}$ \\
\hline 1 & Novice & $\begin{array}{l}\text { Presentation shows work and effort but is vague or missing key elements necessary to } \\
\text { communicate the solution, or, presentation quality is lacking even if designed solution is } \\
\text { complete. }\end{array}$ \\
\hline 0 & No Evidence & Presentation does not communicate the topic. \\
\hline
\end{tabular}

Note: Team discussed that this is an important element to determine student understanding of EDP. * Note: Adapted from SmartLab Project Self-Assessment Rubric.

Guidelines for Proficiency:

- My presentation communicates my design or solution clearly, including models, renderings, and prototypes as appropriate (more than one item from this list required for 4 or 5).

- My presentation incorporated data from multiple sources, including visualizations (more than one data source required for 4 or 5).

- My presentation showcases my expertise in using the software, hardware, or materials that my group used to make our solution.

- I designed my presentation for the appropriate audience.

- I adhered to presentation standards for eye contact, articulation, posture, and timing. 


\section{Appendix B: Middle School Rubric for Engineering Design Logs}

Element A: Identify the Problem

\begin{tabular}{|c|c|l|}
\hline $\begin{array}{c}\text { Score } \\
\text { Point }\end{array}$ & Performance Level & \multicolumn{1}{c|}{ Performance Level Description } \\
\hline 3 & Advanced & $\begin{array}{l}\text { The problem is identified and defined with adequate depth, and it is } \\
\text { sometimes elaborated with specific detail, although some information } \\
\text { intended as elaboration may be imprecise or general. The problem } \\
\text { statement includes a need and a market or client. The problem statement } \\
\text { may imply a certain class of solutions. }\end{array}$ \\
\hline 2 & Proficient & $\begin{array}{l}\text { The problem is identified and defined but may be lacking specific detail. } \\
\text { The problem statement may be a paraphrase of a given problem statement, } \\
\text { but includes at least a need and/or a market or client. The problem } \\
\text { statement may favor a particular solution. }\end{array}$ \\
\hline 1 & Developing & $\begin{array}{l}\text { The identification and/or definition of the problem is unclear and/or is } \\
\text { clearly subjective. The problem statement may imply the solution without } \\
\text { a clear illustration of the need or the client. }\end{array}$ \\
\hline 0 & No Evidence & $\begin{array}{l}\text { The identification and/or definition of the problem are missing OR cannot } \\
\text { be inferred from information included. }\end{array}$ \\
\hline
\end{tabular}

Guidelines for Proficiency:

- I described the exact problem clearly, including a need and a client or market.

- My description of the problem includes information about the background, context, or setting for the problem. 
Element B: Understand

\begin{tabular}{|c|c|c|}
\hline $\begin{array}{l}\text { Score } \\
\text { Point }\end{array}$ & Performance Level & Performance Level Description \\
\hline 3 & Advanced & $\begin{array}{l}\text { Design requirements are listed with dates that indicate when they were added to } \\
\text { the list, and generally include an appropriate source. The requirements are } \\
\text { somewhat measurable, and may lead to a viable solution to the problem } \\
\text { identified. There is evidence that requirements represent the needs of the client or } \\
\text { customer. The sources for the requirements may include evidence of market } \\
\text { research and testing of initial prototypes. Some requirements may be solution } \\
\text { specific. }\end{array}$ \\
\hline 2 & Proficient & $\begin{array}{l}\text { Design requirements are listed with dates that indicate when they were added to } \\
\text { the list along with meaningful sources for some of the requirements. Some/all of } \\
\text { these requirements may be vague or hard to measure, and may not lead to a } \\
\text { viable solution to the problem identified. There is some evidence that the } \\
\text { requirements represent the needs of the client or customer, but sources may not be } \\
\text { credible. There may not be evidence of market research and testing of initial } \\
\text { prototypes. }\end{array}$ \\
\hline 1 & Developing & $\begin{array}{l}\text { An attempt is made to list requirements, but these generally do not include } \\
\text { meaningful sources. The requirements may be partial and/or overly general. } \\
\text { There is little or no evidence that the requirements represent the needs of the client } \\
\text { or customer, and may not include sources. There is no evidence of market research } \\
\text { or testing of initial prototypes. }\end{array}$ \\
\hline 0 & No Evidence & $\begin{array}{l}\text { Design requirements are not presented or do not make sense with respect to the } \\
\text { problem identified. }\end{array}$ \\
\hline
\end{tabular}

Note: The level of requirements that a student provides differentiates between the levels. Additionally, if there are no sources (marketing research etc.), rater should begin no higher than "Developing" level.

Guidelines for Proficiency:

- I listed a set of design requirements (for example: The device must operate correctly more than $90 \%$ of the time.).

- I included a source for each design requirement, such as a client, user, background research, or test results.

- I indicated the date on which each design requirement was added to the list. 
Element C: Ideate

\begin{tabular}{|c|c|l|}
\hline $\begin{array}{c}\text { Score } \\
\text { Point }\end{array}$ & $\begin{array}{c}\text { Performance } \\
\text { Level }\end{array}$ & \multicolumn{1}{c|}{ Performance Level Description } \\
\hline 3 & Advanced & $\begin{array}{l}\text { Multiple sketches for potential solutions were provided; the sketches provided } \\
\text { some detail to communicate each design. }\end{array}$ \\
\hline 2 & Proficient & $\begin{array}{l}\text { One or more sketches for potential solutions were provided; the sketches were } \\
\text { general and provided partial details about each design. }\end{array}$ \\
\hline 1 & Developing & $\begin{array}{l}\text { One or more sketches for a potential solution may have been provided; the } \\
\text { sketches included insufficient detail to communicate each design. }\end{array}$ \\
\hline 0 & No Evidence & No sketches for potential solutions were provided. \\
\hline
\end{tabular}

Note: Student should provide more than one concept, should provide multiple ideas, and should not be merely justifying one preferred idea.

\section{Guidelines for Proficiency:}

- I sketched multiple potential solutions.

- My sketches provided enough details to show each of my designs. (e.g.: labeling key parts or features) 
Element D: Evaluate

\begin{tabular}{|c|c|l|}
\hline $\begin{array}{c}\text { Score } \\
\text { Point }\end{array}$ & $\begin{array}{c}\text { Performance } \\
\text { Level }\end{array}$ & \multicolumn{1}{c|}{ Performance Level Description } \\
\hline 3 & Advanced & $\begin{array}{l}\text { Students used a decision tool to rate each of their potential design solutions. The } \\
\text { process for comparing possible designs solutions based on strengths and } \\
\text { weaknesses was generally defensible. The choice of design solution was explained } \\
\text { with reference to at least some design requirements. }\end{array}$ \\
\hline 2 & Proficient & $\begin{array}{l}\text { Students used a decision tool to rate each of their potential design solutions. The } \\
\text { process for comparing possible design solutions may be superficial. The solution } \\
\text { pathway was not explained with reference to design requirements. }\end{array}$ \\
\hline 1 & Developing & $\begin{array}{l}\text { The proposed design was superficially reviewed based on one or two } \\
\text { considerations. The choice of design solution lacked support related to design } \\
\text { requirements. }\end{array}$ \\
\hline 0 & No Evidence & $\begin{array}{l}\text { There is no evidence provided that a design solution was reviewed based on } \\
\text { design requirements. }\end{array}$ \\
\hline
\end{tabular}

Note: Starting from this element the rater should start reviewing the reflection section. Student should provide more than one concept, should provide multiple ideas, and should not be merely justifying one preferred idea.

\section{Guidelines for Proficiency:}

- I decided if each of my possible solutions might meet the design requirements.

- I described what is good or bad about each design.

- I described why the design solution I chose was the best one to try based on the requirements. 
Element E: Prototyping and Testing

\begin{tabular}{|c|c|l|}
\hline $\begin{array}{c}\text { Score } \\
\text { Point }\end{array}$ & Performance Level & \multicolumn{1}{c|}{ Performance Level Description } \\
\hline 3 & Advanced & $\begin{array}{l}\text { A final prototype (or multiple prototypes, if possible) is designed and/or } \\
\text { constructed with enough detail to assure that most design requirements } \\
\text { could be tested. The tests for each requirement are documented. }\end{array}$ \\
\hline 2 & Proficient & $\begin{array}{l}\text { Prototypes are designed and/or constructed with enough detail to assure } \\
\text { that at least a few design requirements could be tested. The tests for the } \\
\text { requirements are briefly descriped. }\end{array}$ \\
\hline 1 & Developing & $\begin{array}{l}\text { Prototypes are only minimally explained and/or constructed. Test results } \\
\text { may be missing or unclear. }\end{array}$ \\
\hline 0 & No Evidence & $\begin{array}{l}\text { Prototypes are unclear or missing altogether. There is no evidence that } \\
\text { the prototype would facilitate testing by suitable means for any of the } \\
\text { design requirements. }\end{array}$ \\
\hline
\end{tabular}

Note: In the logs, the iteration is embedded in this stage. There is no separate tab for iteration.

\section{Guidelines for Proficiency:}

- I created detailed drawings for my solution.

- Where possible, I created computer models for the solution.

- I built a physical model of my solution.

- I tested my design to show that it meets all of the design requirements. 
Element F: Iteration

\begin{tabular}{|c|c|l|}
\hline $\begin{array}{c}\text { Score } \\
\text { Point }\end{array}$ & $\begin{array}{c}\text { Performance } \\
\text { Level }\end{array}$ & \multicolumn{1}{c|}{ Performance Level Description } \\
\hline 3 & Advanced & $\begin{array}{l}\text { The project designer provides a generally clear reflection on major steps in the } \\
\text { project. The reflection includes at least one lesson learned. There is evidence of } \\
\text { iteration in either design concepts or prototypes. }\end{array}$ \\
\hline 2 & Proficient & $\begin{array}{l}\text { The project designer provides a generally clear reflection on at least one step or } \\
\text { decision made during the project. At least one improvement was made to a design } \\
\text { concept or prototype or a reflection indicates a future improvement plan. }\end{array}$ \\
\hline 1 & Developing & $\begin{array}{l}\text { The project designer provides a reflection on a major step in the project, although } \\
\text { the reflection may be partial, overly-general and/or superficial. There may be no } \\
\text { evidence of improvements or iteration or any plans for iteration. }\end{array}$ \\
\hline 0 & No Evidence & $\begin{array}{l}\text { There is no evidence of a reflection and/or lessons learned. There is no evidence } \\
\text { of iteration or improvement in the design process. }\end{array}$ \\
\hline
\end{tabular}

Note: If the student does not provide more than one concept in the earlier stages, then iteration evidence might not exist. Again, the reflections are important to review for this section.

\section{Guidelines for Proficiency:}

- I made improvements to my design through an iterative process.

- I wrote a reflection about my design process.

- My reflection describes my decisions I made and why I made them.

- My reflection describes what I would do differently if I tried to address the problem again or how I would proceed with improving my solution given more time to do so. 
Element G: Progression

\begin{tabular}{|c|c|l|}
\hline $\begin{array}{c}\text { Score } \\
\text { Point }\end{array}$ & Performance Level & \multicolumn{1}{c|}{ Performance Level Description } \\
\hline 3 & Advanced & $\begin{array}{l}\text { The portfolio provides generally clear documentation of the design process } \\
\text { that would be likely to facilitate subsequent refinement by the designer(s) } \\
\text { and/or others. }\end{array}$ \\
\hline 2 & Proficient & $\begin{array}{l}\text { The portfolio provides partial or sometimes overly general } \\
\text { documentation of the design process and project that would be unlikely to } \\
\text { facilitate subsequent refinement by the designer(s) and/or others. }\end{array}$ \\
\hline 1 & Developing & $\begin{array}{l}\text { The portfolio provides minimal documentation of the design process and } \\
\text { project that would not facilitate subsequent refinement by the designer(s) } \\
\text { and/or others. The portfolio may contain only one design alternative, } \\
\text { indicating fixation. }\end{array}$ \\
\hline 0 & No Evidence & $\begin{array}{l}\text { The portfolio is incomplete, indicating either a lack of a systematic } \\
\text { design process or early evidence of design fixation. }\end{array}$ \\
\hline
\end{tabular}

Note: If only one concept is provided, there is not much evidence of progression.

\section{Guidelines for Proficiency:}

- I reviewed my Engineering design log to make sure I included relevant documentation of each stage of the design process.

- My portfolio provides enough detail to guide someone else in following my design process.

- My portfolio indicates that I followed a true engineering design process driven by customer needs and requirements, and that multiple design solutions were considered and improved throughout the process. 
Element H: Communicate your Solution*

\begin{tabular}{|c|c|l|}
\hline $\begin{array}{c}\text { Score } \\
\text { Point }\end{array}$ & $\begin{array}{c}\text { Performance } \\
\text { Level }\end{array}$ & \multicolumn{1}{c|}{ Performance Level Description } \\
\hline $\begin{array}{c}\text { Score } \\
\text { Point }\end{array}$ & $\begin{array}{c}\text { Performance } \\
\text { Level }\end{array}$ & Performance Level Description \\
\hline 3 & Advanced & $\begin{array}{l}\text { Content: Presentation communicates the topic in a clear and compelling manner, exhibiting a } \\
\text { high level of knowledge on the solution being presented. Presentation includes at least two } \\
\text { types of data (financial, stakeholder, test results, research) with appropriate analysis and } \\
\text { visualizations to justify design decisions and/or present a compelling sales pitch. A designed } \\
\text { solution is communicated using at least one of the following: physical prototypes, drawings, } \\
\text { and renderings, as appropriate. The presentation is audience appropriate. } \\
\text { Skill: Presenter(s) spoke clearly, did not read off of slides, and adhered to the time limits. }\end{array}$ \\
\hline 2 & $\begin{array}{l}\text { Content: Presentation communicates the topic in a somewhat clear and compelling manner. } \\
\text { Presentation exhibits some use data to justify design decisions and/or present a compelling sales } \\
\text { pitch. There is some evidence of data analysis and visualization. A designed solution is } \\
\text { communicated using physical prototypes, drawings, and renderings, as appropriate, but some } \\
\text { details may not be clear. Presentation is mostly audience appropriate. } \\
\text { Skill: Presenter(s) adhered to the time limits and did not read off of slides. }\end{array}$ \\
\hline 1 & Developing & $\begin{array}{l}\text { Content: Presentation communicates a clear design solution or a clear use of data, but maybe } \\
\text { not both. The presentation contains some visual media and a description of the solution. The } \\
\text { presentation may not be tailored to the appropriate audience. } \\
\text { Skill: Presenter(s) adhered to the time limits. }\end{array}$ \\
\hline 0 & No Evidence & $\begin{array}{l}\text { Presentation shows work and effort but is vague or missing key elements necessary to } \\
\text { communicate the solution, or, presentation quality is lacking even if designed solution is } \\
\text { complete. }\end{array}$ \\
\hline
\end{tabular}

Note: Team discussed that this is an important element to determine student understanding of EDP. * Note: Adapted from SmartLab Project Self-Assessment Rubric.

\section{Guidelines for Proficiency:}

- My presentation communicates my design or solution clearly, including models, renderings, and prototypes as appropriate (more than one item from this list required for 4 or 5).

- My presentation incorporated data from multiple sources, including visualizations (more than one data source required for 4 or 5 ).

- My presentation showcases my expertise in using the software, hardware, or materials that my group used to make our solution.

- I designed my presentation for the appropriate audience.

- I adhered to presentation standards for eye contact, articulation, posture, and timing. 